\section{The Investigation of the Relationship Between Mathematics and Science Literacy and Information and Communication Technology Variables}

\author{
Esin Yılmaz Koğar
}

\begin{tabular}{ll}
\hline Received: & 01 December 2018 \\
Revised: & 03 December 2018 \\
Accepted: $\quad 21$ January 2019 \\
ISSN: 1307-9298 \\
Copyright @ IEJEE \\
www.iejee.com
\end{tabular}

DOI: $10.26822 /$ iejee.2019349250

\begin{abstract}
This study attempted to identify the information and communication technology items that affected students' mathematics and science literacy scores by making use of the 2015 PISA data, The presence of numerous items related to ICT in the PISA and the administration of these items to large groups of people provides researchers with a large data source. However, researchers experience challenges in revealing the significant and beneficial data among the entire data set. So one of the most commonly used data mining method is the Chi-squared Automatic Interaction Detection method (CHAID), which is the decision tree method. As a result of the CHAID analysis, conducted to reveal the ICT items related to mathematics literacy scores, it was revealed that there was a significant relationship between mathematics literacy scores and the eight variables. For science literacy, there was a ten significant relationship variables. There is a relationship between high science and mathematics literacy scores and using digital devices at an early age as well as feeling comfortable with using digital devices at home. As an outcome of the CHAID algorithm, the realization of a significant reduction was achieved in the dimensionality of both models. The selected variables can be used for future research and development of new, parametric models. In the resulting model, apart from the reduction of the number of predictors, the reduction of their categories was also achieved.
\end{abstract}

Keywords: Information and Communication Technology, Data Mining, Chaid, Mathematic Literacy, Sciene Literacy

\section{Introduction}

Information and communication technology (ICT) plays a significant role in all spheres of life, including the field of education, where these kinds of resources have gained increasing importance because educational developments should reflect individuals' needs, expectations and interests. Only this kind of a development can make best use of ICT to increase the quality of teaching and learning, share knowledge and information, provide a high degree of flexibility to respond to the needs of the society, decrease the cost of education, and increase internal and external productivity (UNESCO, 2005). The current world is becoming an information society; thus, making developments to facilitate access to information and raising individuals who know how to access information to solve the problems they encounter are among the priorities of societies. Hence, ICT is integrated into learning and teaching environments to develop students' 21st century skills (Kim, Kil, \& Shin, 2014).

ICT is defined as a "diverse set of technological tools and resources used to communicate and to create, disseminate, store, and manage information" (Blurton, 1999). It is rather important to understand how ICT is utilized in educational contexts, what educational goals it caters to, and what role it plays in the success of learning processes (Papanastasiou, Zembylas, \& Vrasidas, 2005). ICT directs educational policies in societies that do not want to fall behind the information age. Numerous countries have enforced policies regarding the use of ICT and made significant investments in resources for the ICT infrastructure of schools (Witte \& Rogge, 2014). Moreover, many research studies in various countries have focused on ICT, which has an important place in educational policies, and thus, made substantial contributions to the related literature.

Du, Harvard, Sansing and Yu (2004) reported that the presence of a computer in students' homes and the frequent use of the computer by the students had a positive impact on the achievement scores of reading and math, which were derived from the 2002 Educational Longitudinal Study database. In another study, conducted by Banerjee, Cole, Duflo, and Linden (2004), a computer assisted learning program was designed and implemented to investigate the impact of this program on students' achievement in mathematics. As a result of the two-year-long investigation of the computer assisted learning program, it was revealed that the level of students' achievement in mathematics had increased in both years, with higher achievement levels in the second year. Hence, the study yielded the finding that the implementation of computer assisted learning had a significantly positive impact on students' achievements in mathematics. Similarly, Kim and Chang (2010) stated that access to a home computer and the use of computers for various purposes had a positive impact on students' achievements in mathematics. In another study, carried out by Valentine, Marsh, and Pattie (2005) reported that the use of ICT within the home had a statistically significant effect on students' levels of achievement in English and mathematics.

In a meta analysis by Torgerson and Zhu (2003), it was maintained that the use of ICT had a positive, but small a degree of impact on student performance. There are other studies in the literature reporting the positive effect of ICT on student learning (Balanskat \& Blamire, 2007; Carrasco \& Torrecilla, 2012; Eng, 2005). Harrison et al., (2002) investigated the achievement of students by analyzing data obtained from ImpaCT2, a large-scale national survey in the United Kingdom. While the study yielded significant results for the five-year-old group of students' achievement in English, the results for the 8- or 10-year-old student group were found to be insignificant. However, it was reported that there was a positive relationship between ICT and student achievement in mathematics. Thus, it can be concluded that there there is a significant relationship between ICT and academic performance of students. 
The increase in interest towards the use of ICT in largescale international assessments in recent years has also led to an increase in the number of studies in this area. Studies conducted by the Trends in International Mathematics and Science Study (TIMSS) and the Programme for International Student Assessment (PISA) include questions related to the use of ICT. Since PISA and TIMSS provide a large source of data on ICT, they have become the most commonly used data for researchers who want to want to conduct research on ICT. PISA, pursued by the Organization for Economic Cooperation and Development (OECD), is an international study measuring 15 -year-old students reading, mathematics and science literacies. Since the year 2000, PISA has included various questions regarding the use of ICT, including questions about the access to technical tools and devices, the frequency of using them and self-efficacy beliefs. Hence, the number of ICT studies making use of data from PISA is considerably high. According to the 2003 PISA results, it was revealed that students who made regular use of the computer had a higher level of achievement in the core academic subjects (OECD, 2006). Similarly, using the 2000 PISA data of the U.S.A., Papanastasiou and Ferdig (2006) revealed that using the computer at home had a positive impact on achievement in mathematics. Based on the results of the 2009 PISA, Lee and $\mathrm{Wu}$ (2012) reported that the presence of ICT equiment within the home environment contributes to the development of students' reading and writing skills. Furthermore, in a study where data from large-scale exams of various countries were used, Skryabin, J. Zhang, Liu and D. Zhang (2015) investigated how the development level in ICT and individual use of ICT affected 4th and 8th grade students' achievements in reading, mathematics and science. Based on the results of the study, it was determined that development level in ICT was a significant, positive predictor of students' individual academic performance. Similarly, by conducting a study based on the 2000 PISA data, Fuchs and Woessmann (2005) revealed that there was a positive relationship between achievement and access to a computer both at home and at school. However, when the variables of family background and school characteristics were controlled, a negative relationship was found between achievement in mathematics and having access to a computer in the home environment, and no relationship was found between achievement in mathematics and having access to a computer in the school environment. They found that computers within the home environment had a positive impact only for certain purposes (e.g. e-mail and web pages). Similarly, Wittwer and Senkbeil (2007), who examined the 2003 PISA data of German students, reported in their study that there was no association between students' access to a computer in the home environment and their mathematics performance.

When these previous studies in the literature were examined, it was observed that the impact of ICT on learning outcomes was positive and significant at a moderate degree, while findings yielded by studies on the relationship between use of BIT and student performance were more complicated (Skryabin et. al, 2015). Issues related to the impact of ICT on educational processes, such as communication, learning and lifestyle are still being discussed by means of studies conducted in the related literature. Whether or not ICT really supports and develops learning and increases the quality of education were investigated through these discussions. Thus, by making use of the 2015 PISA data, the present study attempted to identify the information and communication technology items that affected students' mathematics and science literacy scores. The presence of numerous items related to ICT in the PISA and the administration of these items to large groups of people provides researchers with a large data source. However, researchers experience challenges in revealing the significant and beneficial data among the entire data set. One of the methods resorted to in order to overcome this challenge is data mining (DM). DM aims to analyze the data obtained through various means to transform them into a comprehensible structure. DM has been developed as a multidisciplinary approach by which abundant data can be analyzed rapidly and defines the important models disguised in the data set (Milanović \& Stamenković, 2016). Even though there are numerous methods in data mining, one of the most commonly used methods is the Chi-squared Automatic Interaction Detection method (CHAID), which is the decision tree method. CHAID, which enables the independent variables related to the dependent variables and the related data to be revealed as much as possible, categorizes the data set into more homogenous subgroups. Pursuing the study by categorizing the the whole into its components and categorized probable subgroups can lay a more realistic foundation for researchers and in this way the assumption of homegeneity, which is considered important in statistics, is secured (Kadri \& Boysan, 2007). Moreover, this method enables the inclusion of both continuous and categorical data at the same time. What's more, it facilitates the interpretations of the results as it provides a visual presentation of the relationships between CHAID and dependent and independent variables. The first phase of the tree, formed as a result of the CHAID analysis, begins with the division of a starting independent variable into dependent variables as categories or value intervals displaying statistically significant differences. This categorization continues until significant variables can no longer be calculated statistically. The chi-square test is used for categorizations in which the dependent variable is categorical, while in situations where the dependent variable is continuous, the algorithm utilizes the F test (Rokach \& Maimon, 2008).

\section{Method}

The present study, which aimed to examine the ICT factors related to students' mathematics and science literacy scores by means of CHAID analysis, adopted the survey method. In this study, secondary analyzes were made by using PISA data and the current situation was tried to be revealed.

\section{Sample of the Study}

The data sources for this research include the PISA 2015 datasets. The data of 35 OECD countries were used in the study. Data from a total of 248620 individuals from these 35 countries were collected. However, since the "Information and Communication Technologies Survey" was not done by four OECD countries, based on their own preference, (Canada, Norway, Turkey, the United States), 5000 cases were selected randomly from among the dataset of 208388 cases from the remaining 31 countries. After data cleaning and the exclusion of missing data, the final sample contained 2307 cases in the PISA 2015 dataset.

\section{Data Collection Instruments}

As data collection tools in the study, the ICT Familiarity Questionnaire used in the 2015 PISA and the Scientific and Mathematical literacy tests were utilized.

Information and Communication Technology Familiarity Questionnaire. ICT Familiarity Questionnaire (ICQ) is an 81 -item questionnaire administered to students based on countries' preferences. After the student questionnaires were completed, they were administered ICQ, which took 10 minutes to complete. These 81 items were selected as the independent variables of the study. 
Scientific and Mathematical Literacy Tests. In PISA, students are administered three different tests, namely reading, science literacy and mathematics literacy tests. In each administration, one of the three areas is chosen to be primary, so fewer items are included from the other two areas. The primary area in PISA 2015 was science literacy. In 72 countries where PISA 2015 was administered, these tests were administered via either computer-based assessment (57 countries) or pen and paper based assessment (15 countries). For the computer based assessment, 66 different booklets, and for the pen and paper based assessment, 30 different booklets were formed. Each booklet consisted of four sections, each lasting 30 minutes (Taş, Arıcı, Ozarkan, \& Özgürlük, 2016). The PISA 2015 administration consisted of two sittings, each given 60 minutes, and there was a 5-10-minute break between the two sittings. Approximately 65 percent of the science items were multiple-choice and 35 percent of them were open-ended questions. Of the mathematics items, approximately 40 percent were multiple choice and 60 percent were open-ended items (Kastberg, Chan, \& Murray, 2016). However, students do not answer all the questions in the PISA. Predictions of students' unobserved responses aremade based on students' observed responses and thus 10 different probable values are predicted (plausible values-PVs). In the PISA 2015 data file, the predicted values for mathematics literacy were named as PV1MATHPV10MATH, while those for science literacy were named as PV1SCIE-PV10SCIE. As the correlations among the 10 different PVs for mathematics and science were considerably high (.85 and above), for both domains, PV1s were selected as dependent variables.

\section{Data Analysis}

Detailed information related to the variables used in the current study is presented in Table 1 in the Appendix. The CHAID decision tree method, one of the multivariate analysis methods, was used in order to identify which independent variables were highly related with which dependent variables and to examine the dominance among these variables. As the depedent variables used in the present study were continuous, the CHAID algorithm $\mathrm{F}$ test was used to identify the factors related with dependent variables and at which level of these factors there were strong relationships.

In the alogrithm used, CHAID, as method becoming increasingly common, was utilized, $Y_{1}$ and $Y_{2}$ were used separately as dependent variables, $\mathrm{X}_{1}, \mathrm{X}_{2}, \mathrm{X}_{3}, \ldots, \mathrm{X}_{81}$ were used as independent variables (see Table 1), cross-validation was used as a method of validation, and specifications were set as follows: maximum tree depth:3, minimum cases in parent node:40, minimum cases in child node: 15 . The level of significance was set as $\alpha=0.05$ for node splitting. Whether or not the variables were appropriate for splitting was decided on by utilizing the Bonferroni corrected $p$ value. In addition, during the process of model construction, the ten-fold cross-validation model was performed.

Findings

Upon the examination of the decision tree derived from the CHAID analysis, in which the mathematics literacy scores were the dependent variable and a total of 81 variables in the ICT Familiarity Questionnaire were the dependent variables, it was observed that the model consisted of three depths and total of 23 nodes, of which 12 were terminal. In addition, from a total of 81 initially specified independent variables, the final model included eight, while the remaining 73 were not statistically significant from in terms of their association with the score of mathematical literacy. As can be observed in Figure 1, students' average score in mathematics literacy and the standard deviation was found to be 512.94 and 89.118 , respectively. Based on this average, it can be concluded that the mathematics literacy of the students constituting the sample of the study corresponds to level 3.

The variable with the highest $F$ value among the independent variables having a statistically significant relationship between the dependent variables has first place in the decision tree that was formed. In the present study, the independent variable having the highest relationship with mathematics literacy scores was found to be the variable coded as $X_{19}\left(F_{(2,2304)}=84.844, p<.001\right)$. This finding demonstrates that $X_{1}$ is the independent variable that has the strongest relationship with the dependent variable and has the greatest strength in the splitting of the nodes into sub-nodes. As a result of this analysis based on the mathematics literacy scores, 2307 participants were split into three sub-nodes, which included different categories of the $X_{19}$ variable, which is related to whether or not there were ebook readers in the school for students to read. For $X_{19}$ within the first level of the tree, nodes 1,2 and 3 are parent nodes. It was revealed that the highest mathematics literacy score mean belonged to the students who did not have e-book readers to use in their schools (node 1), while the lowest mathematics literacy score average belonged to the students who did have the e-book reader to use and who reported to be using this device (node 3 ).

The split of node 2 is based on $X_{27}\left(F_{(1,148)}=13.190, p<.01\right)$, producing the following two groups: node 7 and node 8 , which contain less than or equal to 31-60 minutes per day and more than 31-60 minutes per day, respectively. When nodes 7 and 8 are examined, it can be observed that students whose duration of Internet use was longer had higher mathematics literacy score average. The split of node 3 is based on $X_{62}\left(F_{(1,238)}=14.268, p<.01\right)$, producing the following two groups: those stating disagreement or strongly disagreement (node 9), and those stating agreement or strongly agreement (node10). The average mathematics literacy score of the students who agreed that the Internet is a great source for the topic of interest was found to be higher when compared to those who expressed disagreement. Regarding this tree level, for $X_{45}$ nodes 4,5 and 6 are parent nodes, and for $X_{27}$ node 7 is terminal, while node 8 is parental and for $X_{62}$ node 9 is terminal, while node 10 is parental.

In the third level of the tree depth, the variable that is statistically significant for splitting node 4 is the frequencies of students' downloading/uploading/browsing the school website out of school, $X_{46}\left(F_{(1,1415)}=68.255, p<.001\right)$. These nodes are node 11 , which consisted of students who never or hardly ever downloaded/uploaded/browsed the school website out of school boundaries, and node 12 which comprised students who did so. Of the mathematics literacy scores in each of these two nodes, those that belonged to the students who used the school website were observed to be higher. The variable that is statistically significant for splitting node 5 is the $X_{69}$ coded variable, which refers to the situation of whether or not the student is comfortable with using his/her own digital device in his/her home $\left(F_{(2,308)}=15.910, p<.001\right)$. When node 13, comprised of students expressing strong disagreement or disagreement with this statement, node 14 , comprised of students who stated agreement and node 15, expressing strong agreement, were examined, it was observed that the highest average score belonged to node 5 . Based on this finding, it can be maintained that the mathematics literacy scores of the students with the perception that they could comfortably use the digital device at home were higher. The variable that significantly categorized node 6 is the X67 coded variable, which refers to the whether or not 


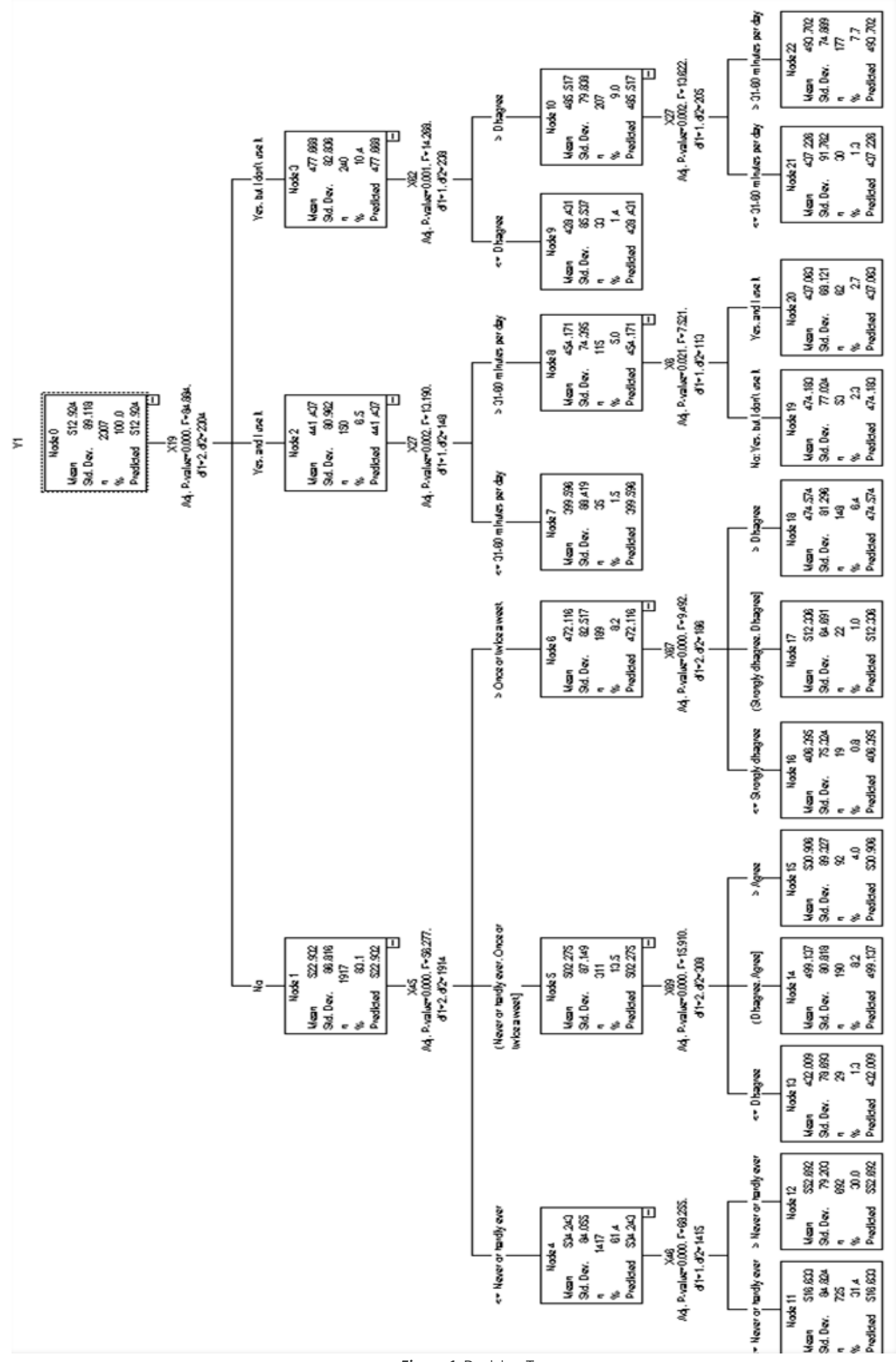


students feel comfortable when using an unfamiliar digital device $\left(F_{(2,186)}=9.492, p<.001\right)$. When node 16 , comprised of students who expressed strong disagreement, node 17 , consisting of students expressing disagreement or strong agreement, and node 18, consisting of students expressing agreement or strong agreement are examined, it can be observed that the highest average score belonged to node 17. When Figure 1 is examined, it can be observed that the variable that significantly categorized node 8 into sub-nodes was the $X_{6}$ coded variable, which refers to whether or not there was access to a telephone with no Internet access $\left(F_{(1,113)}=7.521, p<.05\right)$. Node 19 consisted of students who marked "No" or "Yes, but I don't use it" for this statement node 20 was comprised of students who marked "Yes, and I use it." Since the average mathematics literacy score of the students in node 19 was higher it can be deduced that a mobile telephone with no Internet access did not increase students' mathematics literacy scores. The variable that split node 10 - the last parent node - into sub-nodes (which also split node 2 into significant nodes) is observed to be the $\mathrm{X}_{27}$ coded variable, which refers to the situation related to the duration of Internet use out of school at the weekend $\left(F_{(1,205)}=13.622, p<.01\right)$. It produced the following two groups: node 21 and node 22, which contained less than or equal to 31-60 minutes of Internet use per day and more than 31-60 minutes per day, respectively. When node 21 and node 22 were examined it was found that the students who used the Internet for longer durations had higher mathematics literacy scores.

The categorization process in CHAID analysis does not end until the entire performance of the model is evaluated. None of the results examined so far indicate whether this is a particularly good model (IBM-SPSS, 2012). Thus, the risk estimate table, displaying the model performance, also needs to be considered. For scale dependent variables, the risk estimate is within-node variance and lower variance indicates a better model, but the variance is relative to the unit of measurement (IBM-SPSS, 2012). The crossvalidated risk estimate for the final tree is calculated as the average of the risks for all of the trees. Tables 2 presents basic information about the performance of the developed CHAID model in terms of its accuracy and predictive potential.

Table 2. Risk for mathematical literacy score

\begin{tabular}{ccc}
\hline Method & Estimate & Std. Error \\
\hline Re-substitution & 6572.308 & 198.909 \\
\hline Cross-Validation & 7020.372 & 214.922 \\
\hline
\end{tabular}

To interpret risk estimate meaningfully, a multistaged computation needs to be done (IBM-SPSS, 2012). The within-node variance is the risk estimate value for the re-substitution model: 6572.31. The standard deviation displayed at the root node is 198.91; so the total variance is that value squared: 39564.74 . The proportion of variance due to error (unexplained variance) is 6572.31/39564.74= 0.166 . The proportion of variance explained by the model is $1-0.17=0.834$ or $83.4 \%$, which indicates that this is a fairly good model, while that risk, when a test sample is used in model cross-validation, is 0.848 or $84.8 \%$.

The decision tree, which belonged to the CHAID analysis in which the science literacy scores were addressed as the dependent variable and a total of 81 variables in the ICT Familiarity Questionnaire is addressed as independent variables, is a rather large diagram including 33 nodes. That is why the figure of this decision tree was not included in the present study; only the interpretations were made. Of these 33 nodes, 22 were terminal nodes and were identified as depth 3 . The students' average science literacy score and the standard deviation were calculated as 518.18 and 91.922 , respectively. Based on this average score, it can be deduced that the science literacy of the students comprising the sample of the study was at level 3 (OECD, 2017, p.283).

As a result of the CHAID analysis, the independent variable that has the strongest relationship with the dependent variable of science literacy scores and the strongest ability of splitting the nodes into subnodes was found to be X45students' use of social network for communicating with their teachers $\left(F_{(2,2304)}=112.434, p<.001\right)$. Three sub-nodes were formed to include the categories of the $X_{45}$ variable. For $\mathrm{X}_{45}$ within the first level of the tree, nodes 1,2 and 3 are parent nodes. Node 1 consists of 1596 students who stated that they never or hardly ever communicated with their teachers via social network, node 2 is comprised of 233 students stating that they communicated with their teachers once or twice a month, and node 3 consists of 478 students stating that they communicated with their teachers more than once or twice a month. When nodes 1, 2 or 3 are examined, it can be observed that students' science literacy scores decrease as the frequency of communication with their teachers via social network out of school boundaries increases.

Within the second level of the tree, three statistically significant variables were identified, which are $X_{22}$ - the age at which students first used a digital device, $X_{69}$ - whether or not students were comfortable with using their own digital device at home, and $\mathrm{X}_{19}$ - whether or not there was an ebookreader for students to use at school. Variable $X_{22}$ was found to be significant for splitting of node $1\left(\mathrm{~F}_{(3,1592)}=\right.$ 33.086, $p<.001$ ). Accordingly, the categories formed by four groups of respondents are as follows: node 4 consists of 562 students stating that they were 6 years or younger when they first used a digital device, node 5 consists of 654 students who stated that they first used a digital device at 7-9 years of age, node 6 is comprised of 316 students stating that they first used a digital device at the age of 10-12 years and node 7 consists of 64 students who reported that they first used a digital device when they were 13 years or older. When the nodes formed by the ages at which a digital device was first used were examined, it was revealed that the highest science literacy scores belonged to node 4 and that the higher the age at which the first digital device was used, the lower these average scores were. Variable $X_{69}$ was found to be significant for splitting of node $2\left(F_{(2.230)}=20.385, p<.001\right)$. A comparative examination of node 8 , comprised of students stating strong disagreement or disagreement, node 9 , consisting of students indicating agreement, and node 10 , consisting of students stating strong agreement, shows that the highest average score belongs to node 10 . Based on this finding, it can be deduced that students who hold the perception that they can easily use digital devices at home have higher science literacy scores. The variable that was found to split node 3 into signiticant sub-nodes was found to be the $X_{19}$ coded variable $\left(F_{(1.46)}=23.944, p<.001\right)$. As a result of this analysis conducted based on science literacy scores, it was found that 315 students who gave the response "No" to the variable of wether or not there was an ebookreader for students to use at school formed node 11 and 163 students who gave the response "Yes" formed node 12. When these nodes are compared, it can be observed that the average science literacy scores of students who did not have an ebookreader at school were higher.

In the third level of the tree depth, the variable that was found to be statistically significant for splitting node 4 was $X_{39}$ - Use digital devices out of the school for downloading new apps on a mobile device $\left(\mathrm{F}_{(2.559)}=22.063, p<.001\right)$. Node 13 was formed of 300 students who reported less than or equal to once or twice a month, node 14 was com- 
prised of 213 students who reported once or twice a week or almost every day, and node 15 was composed of 75 students who reported every day. The highest science literacy average score was found to belong to node 13. According$l y$, it can be deduced that the higher the frequency of using digital devices outside school for downloading new apps on a mobile device was, the lower the students' average scores were. The variable that was found to be statistically significant for splitting node 5 was $X_{40}\left(F_{(1,652)}=34.313, p<\right.$ $.001)$. For this variable, which refers to the frequency of browsing the Internet for schoolwork, two nodes - node 16 and node 17 - were formed. When these nodes were examined, it was found that the average score of the students who never or hardly ever browsed the Internet for schoolwork was lower when compared to those students who reported browsing the Internet for schoolwork at least once or twice a month. Based on this finding, it can be deduced that the higher the frequency of students browsing the Internet for schoolwork was, the higher their science literacy scores were. The variable that was found to be statistically significant for splitting node 6 was $X_{36}$ $\left(F_{(2,313)}=12.9003, p<.001\right)$. Three nodes -node 18 , node 19 and node 20 - were formed for this variable related to the frequency of using digital devices outside school for obtaining practical information from the Internet. When the average scores in these nodes were examined, it was revealed that the science literacy scores of students who used digital devices outside school for obtaining practical information from the Internet almost every day were higher. The variable that was found to be statistically significant for splitting node 7 was $X_{37}\left(F_{(2.61)}=7.725, p<.01\right)$. This variable, related to using digital devices outside school for downloading music, films, games or software from the Internet, was split into three nodes, namely node 21 , node 22 , and node 23 . It was revealed the students who reported once or twice a month or once or twice a week for this variable had a higher science literacy average score. However, it was observed that node 23 , which was composed of students reporting more than once or twice a week, had a lower average score in science literacy when compared to the other two nodes. For this reason, it can be deduced that there is a negative relationship between the student scores and the frequent use of the Internet for downloading music, films, games or software.

The variable that was found to be statistically significant for splitting node 9 was $X_{22}\left(F_{(1,146)}=15.428, p<.001\right)$. This variable is related to the age of the student at which a digital device was first used. Node 24 consisted of 108 students who stated that they first used a digital device when they were younger than or equal to 7-9 years of age, while node 25 was comprised of students who reported above 7-9 years of age. A higher science average was yielded in node 24 . Based on this finding, it can be deduced that using digital devices at younger ages increases students' science literacy scores. The variable that was found to be statistically significant for splitting node 10 was the previously mentioned $\mathrm{X} 40$ variable $\left(\mathrm{F}_{(1,59)}=7.806, p<.05\right)$. For this variable related to the frequency of browsing the Internet for schoolwork, two nodes were formed - node 26 and node 27. When these nodes were examined, it was revealed that the average score of the students who reported that they browsed the Internet for schoolwork less than or equal to once or twice a month was lower than those who reported at least once or twice a month.

The variable that was found to be statistically significant for splitting node 11 was the previously mentioned $X_{27}\left(F_{12}\right.$ $\left.{ }_{312)}=9.361, p<.01\right)$. Three nodes - node 28 , node 29 and node 30 - were formed related to duration of students' use of the Internet outside of school at weekends. When these nodes were examined, it was revealed that the highest average science scores were obtained from the cat- egories of 31-60 minutes per day and between 4 hours and 6 hours per day. It was revealed that the as the duration of Internet usage was shorter than 31-60 minutes or longer than between 4 and 6 hours per day, the lower the students' scores were. The variable that was found to be statistically significant for splitting node 12 was $X_{75}\left(F_{12}\right.$ $\left.{ }_{160)}=7.900, p<.01\right)$. Node 3 was found to be comprised of 31 students who strongly disagreed or disagreed with the statement, "If I have a problem with digital devices I start to solve it on my own," while node 32 was composed of 95 students who agreed, and node 33 consisted of 37 students who strongly agreed. It was revealed that the group with the highest science literacy average was node 33.

The risk table obtained to evaluate whether or not the model constructed for science literacy is presented in Table 3 .

Table 2. Risk for scientific literacy score

\begin{tabular}{ccc}
\hline Method & Estimate & Std. Error \\
\hline Re-substitution & 6675.081 & 190.544 \\
\hline Cross-Validation & 7464.804 & 214.678 \\
\hline
\end{tabular}

The proportion of variance explained by the model with the re-substitution model is 0.816 or $81.6 \%$, and when a test sample is used in model cross-validation, the proportion of variance explained is 0.838 or $83.8 \%$, which indicates that this is a fairly good model.

\section{Discussion, Conclusions and Recommendations}

As a result of the CHAID analysis, conducted to reveal the ICT items related to mathematics literacy scores, it was revealed that there was a significant relationship between mathematics literacy scores and the variables coded as $\mathrm{X}_{19}, \mathrm{X}_{45}, \mathrm{X}_{46}, \mathrm{X}_{69}, \mathrm{X}_{67}, \mathrm{X}_{27}, \mathrm{X}_{6,}, \mathrm{X}_{62}$

Of these variables, the variable that yielded the most important relationship with mathematics literacy scores was X19: Digitial devices available at school: <ebook reader>. It was revealed that the highest mathematics literacy average score belonged to students who did not have an ebookreader in their school, while the lowest mathematics literacy average score belonged to those students who had an ebookreader that they could and did use in their school. This result could have derived from the fact that students in the field of mathematics do computations based more on pen and paper. Another striking finding of the study is that the higher the frequencies of students' use of social network for communicating with their teachers were, the lower their mathematics literacy scores were. This could stem from the fact that students may not be limited to communicating with their teachers on social network, but deviating from these platforms when they are online in these social networks, which can be time consuming. Moreover, it was revealed that using digital devices and the Internet for education purposes had a positive effect on mathematics literacy scores. The findings of the study revealed that among the categorizations made, those who had higher mathematics literacy scores were those student who used the Internet for longer periods of time, who agreed with the view that the Internet was a great source in relation to topics of interest, who downloaded/uploaded/browsed their school website more frequently, who felt comfortable using their own digital device at home, who did not feel comfortable using an unfamiliar digital device, and who reported that they had access to a mobile phone with Internet connection at home, but did not use it. Based on these findings, it can be concluded that there is a relationship between mathematics literacy scores and the conditions of ICT being available at school, ICT being used outside of school for schoolwork, 
and students' perceived ICT competence.

As a result of the CHAID analysis, conducted to reveal the ICT items related to science literacy scores, it was revealed that there was a significant relationship between science literacy scores and the variables coded as $X_{45}, X_{22}, X_{39}, X_{40}$ $X_{36}, X_{37}, X_{69}, X_{19}, X_{27, \text { and }} X_{75}$. Of these variables, the variable that yielded the most important relationship with science literacy scores was X45: Frequency of use outside of school: Using Social Networks for communication with teachers. It was revealed that similar to the condition with mathematics literacy scores, there was a decrease in students' science literacy scores as the frequency of students' use of social network for communication with their teachers increased. Another variable that was revealed to have a negative relationship with science literacy scores was the increase in the age at which a digital device was first used. It can be claimed that the condition in which a student uses a digital device at a young age increases science literacy scores. Another variable that has been revealed to have a significant relationship with science literacy scores was digitial devices available at school: <ebook reader>. It was observed that with respect to this variable, as was the case in mathematics literacy scores, those students who did not have an ebookreader in their school had higher science literacy scores. The higher the frequency of students' use of digital devices outside school for downloading new apps on a mobile device was, the lower the students' science literacy scores were. This condition could be attributed to the fact that students may not be using these devices for educational purposes. When the overall categorization for science literacy is viewed, it can be concluded that there is a relationship between students' science literacy scores and ICT use outside of school leisure, ICT use outside of school for schoolwork, and students' perceived autonomy related to ICT use.

As a result of the analyses in which two different dependent variables were used, it was revealed that there was a significant relationship between the $\mathrm{X}_{19}, \mathrm{X}_{27}, \mathrm{X}_{45}, \mathrm{X}_{69}$ variables and both mathematics and science literacy. When the results obtained from these variables were generally examined, it can be deduced that the conditon of merely having and using ICT does not relationship with the mathematics and science literacy scores. For what purpose students use ICT should also be investigated. There is a relationship between high science and mathematics literacy scores and using digital devices at an early age as well as feeling comfortable with using digital devices at home. As an outcome of the CHAID algorithm, the realization of a significant reduction was achieved in the dimensionality of both models. The selected variables can be used for future research and development of new, parametric models. In the resulting model, apart from the reduction of the number of predictors, the reduction of their categories was also achieved. For example, in its original form, variable $X_{27}$ (IC007Q01TA) has 7 categories (Table 1), and 2 categories in the model (Figure 1).

As previously mentioned in the present article, there are numerous studies on ICT in the literature and different findings are reported. In the present study, it was revealed that of the items related to frequency of using social network, student performance is only significantly related to the use of social network when communicating with the teacher. However, this is a one-way relationship.

Similar to this finding of the present study, Paul, Baker and Cochran (2012) reveals a statistically significant negative relationship between time spent on social networks and academic performance. Similarly, Karpinski \& Duberstein (2009) reported that students who frequently used social network services had decreased levels of productivity in academic environments. It was mentioned in a study by Englander, Terregrossa and Wang (2010) that social net- work was generally not used for academic purposes, which could cause problems in the area of student achievement. However, there is no agreement in the literature in this area as well. Rideout (2012) reported that the students who used social media according to the teachers made $54 \%$ progress in their maths skills and $51 \%$ progress in their science skills. Thus, to arrive at a decision concerning social network, more attention needs to be placed upon for what purposes these networks are used rather than the amount of time spent on the social network or who are contacted.

In the present study, it was concluded that the presence of e-bookreaders, which are mobile devices, in the schoo does not increase students' science and mathematics literacy scores. This result coud be attributed to the fact that students are more familiar to traditional classrooms, they cannot easily access the Internet, and the subjects under study are numeric subjects. However, different from the finding of the current study, in a study by Larson (2010), in which conditions where eReaders, particularly Kindle, were used to read eBooks in class were examined, it was revealed that use of Kindle resulted in a better interaction with the text and a deeper conceptualization. Another finding of the current study was that having access to technology at young ages increased literacy scores. In a study conducted with pre-school teachers, Sandberg (2002) reported that pre-school teachers believed that use of ICT in their classrooms was important for the cognitive development of students. It was also revealed that there was a relationship between students' use of ICT outside of school for schoolwork and their academic achievements. Underwood, Billingham and Underwood (1994) stated that experiences with the computer out of the school could have an impact on students' school achievement levels. As in the metaanalysis study by Torgerson and Zhu (2003), in the present study, the fact that use of ICT increases student performance can be emphasized.

The findings which the present study yielded seems to be consistent with the fact that there is a relationship betwen students' use of ICT and their mathematics and science literacy scores. However, to reveal the reasons or effects of this relationship, experimental or qualitiatives studies need to be conducted in this area. The ICT items addressed as independent variables in the present study are noncontinuous variables. By using almost all of the items in the ICT questionnaire in PISA, nine separate index scores were established. These variables, which were made continuous, can be included in the study as indepedent variables. The relationships, which were tried to be revealed via CHAID, a nonparametric analysis method, could be examined by utilizing more powerful statistical methods. As there are ICT items in the questionnaires of TIMSS as well, a similar study could be replicated with the data of TIMSS. Educational programs in which use of ICT for academic purposes is encouraged can be constructed, and teachers can be provided with seminars on the effective use of ICT.

\section{References}

Balanskat, A., \& Blamire, R. (2007). ICT in schools: Trends, innovations and issues in 2006-2007. Brussels: European Schoolnet.

Banerjee, A. V., Cole, S., Duflo, E., \& Linden, L. (2007). Remedying education: Evidence from two randomized experiments in India. The Quarterly Journal of Economics, 122(3), 1235-1264. Retrieved from https://www.jstor.org/stable/pdf/25098872.pdf

Blurton, C. (1999). New directions of ICT-use in education. Paris, France: UNESCO. Retrieved from http://www. unesco.org/education/educprog/lwf/dl/edict.pdf 
Carrasco, M. R., \& Torrecilla, F. J. M. (2012). Learning environments with technological resources: A look at their contribution to student performance in Latin American elementary schools. Educational Technology Research and Development, 60(6), 1107-1128. Doi:10.1007/s11423-012-9262-5

Du, J., Haward, B., Sansing, W., \& Yu, C. (2004). The ımpact of technology use on low-Income and minority students' academic achievements: Educational longitudinal study of 2002. Journal of Educational Research \& Policy Studies, 4(2), 21-38. https://files. eric.ed.gov/fulltext/ED485086.pdf

Eng, T. S. (2005). The impact of ICT on learning: A review of research. International Education Journal, 6(5), 635-650. Retrieved from https://files.eric.ed.gov/ fulltext/Ej855017.pdf

Englander, F. Terregrossa, R. A. \& Wang, Z. (2010). Educational review. Journal of Education 62(1), 85-96. Retrieved from http://books.google.com.gh/books?id7MpDOE.

Fuchs, T., \& Woessmann, L. (2004). Computers and student learning: Bivariate and multivariate evidence on the availability and use of computers at home and at school. Munich: Ifo Institute for Economic Research. Retriewed from https://www.econstor.eu/bitstream/10419/18686/1/cesifo1_wp1321.pdf

Harrison, C., Comber, C., Fisher, T., Haw, K., Lewin, C., Lunzer, E.,\& Watling, R. (2002). ImpaCT2: The impact of information and communication technologies on pupil learning and attainment. British Educational Communications and Technology Agency (BECTA).

IBM SPSS (2012). Decision Trees 21. http://www.sussex. ac.uk/its/pdfs/SPSS_Decision_Trees_21.pdf

Kayri, M., \& Boysan, M. (2007). Araştırmalarda CHAID analizinin kullanımı ve baş etme stratejileri ile ilgili bir uygulama. Ankara Üniversitesi Ĕgitim Bilimleri Fakültesi Dergisi, 40(2), 133-149. Retriewed from http:// dergipark.gov.tr/download/article-file/509058

Karpinski, A. C., \& Duberstein, A. (2009). A description of Facebook use and academic performance among undergraduate and graduate students. In Annual Meeting of the American Educational Research Association, San Diego, CA (pp. 5-10).

Kastberg, D., Chan, J. Y., \& Murray, G. (2016). Performance of US 15-year-old students in science, reading, and mathematics literacy in an international context: First look at PISA 2015. NCES 2017-048. National Center for Education Statistics. Retriewed from https://files.eric.ed.gov/fulltext/ED570968.pdf

Kim, S., \& Chang, M. (2010). Does computer use promote the mathematical proficiency of ELL students? Journal of Educational Computing Research, 42(3), 285-305. Doi:10.2190/EC.42.3.c

Kim, H., Kil, H., \& Shin, A. (2014). An analysis of variables affecting the ICT literacy level of Korean elementary school students. Computers \& Education, 77, 29-38. Doi:10.1016/j.compedu.2014.04.009

Larson, L. C. (2010). Digital readers: The next chapter in eBook reading and response. The Reading Teacher, 64, 15-22. Doi:10.1598/RT.64.1.2

Lee, Y. H., \& Wu, J. Y. (2012). The effect of individual differences in the inner and outer states of ICT on engagement in online reading activities and PISA
2009 reading literacy: Exploring the relationship between the old and new reading literacy. Learning and Individual Differences, 22(3), 336-342. Doi:10.1016/j.lindif.2012.01.007

Milanović, M., \& Stamenković, M. (2016). CHAID decision tree: Methodological frame and application. Economic Themes, 54(4), 563-586. Doi:10.1515/ethemes-2016-0029

OECD (The Organisation for Economic Co-operation and Development). (2006). Are students ready for a technology-rich world?: What PISA studies tell us. Retriewed from http://www.oecd.org/education/ school/programmeforinternationalstudentassessmentpisa/35995145.pdf

OECD (The Organisation for Economic Co-operation and Development). (2017). Technical report. Retriewed from https://www.oecd.org/pisa/sitedocument/PISA-2015-technical-report-final.pdf

Papanastasiou, E., \& Ferdig, R. E. (2006). Computer use and mathematical literacy: An analysis of existing and potential relationships. Journal of Computers in Mathematics and Science Teaching, 25(4), 361-371.

Papanastasiou, E., Zembylas, M., \& Vrasidas, C. (2005). An examination of the PISA database to explore the relationship between computer use and science achievement. Educational Research and Evaluation, 11(6), 529-543. Doi:10.1080/13803610500254824

Paul, J. A., Baker, H. M., \& Cochran, J. D. (2012). Effect of online social networking on student academic performance. Computers in Human Behavior, 28(6), 2117-2127. Doi:10.1016/j.chb.2012.06.016

Rideout, V. (2012). Children, teens, and entertainment media: The view from the classroom. A Common Sense Media Research Study. Retrieved from https://www. commonsensemedia. org/ research/children-teens-and-entertainment-media-the-view-from-the-classroom.

Rokach, L. \& Maimon, O. (2008). Data mining with decision trees: Theory and applications. New Jersey (etc.): World Scientific.

Sandberg, A. (2002). Preschool teacher's conceptions of computers and play. Information Technology in Childhood Education Annual, 2002(1), 245-262. Retriewed from https://www.learntechlib.org/p/10766/article_10766.pdf

Skryabin, M., Zhang, J., Liu, L., \& Zhang, D. (2015). How the ICT development level and usage influence student achievement in reading, mathematics, and science. Computers \& Education, 85, 49-58. Doi:10.1016/j.compedu.2015.02.004

Taş, U. E., Arıcı, Ö., Ozarkan, H. B., \& Özgürlük, B. (2016). PISA 2015 ulusal raporu. Ankara: MEB. Retriewed from http://pisa.meb.gov.tr/wp-content/uploads/2016/12/PISA2015_Ulusal_Rapor.pdf

Torgerson, C., \& Zhu, D. (2003). A systematic review and meta-analysis of the effectiveness of ICT on literacy learning in English, 5-16. EPPI-Centre, Social Science Research Unit, Institute of Education, University of London.

Underwood, J., Billingham, M., \& Underwood, G. (1994). Predicting Computer Literacy: How do the technological experiences of schoolchildren predict their computer-based problem-solving skills?. Journal of 
Information Technology for Teacher Education, 3(1),

115-126. Doi:10.1080/0962029940030110

UNESCO (2005). information and communication technologies in schools: A handbook for teachers or how Ict can create new. Open Learning Environments. Paris: UNESCO Publication. Retrieved from http://unesdoc.unesco.org/images/0013/001390/139028e. pdf

Valentine, G., Marsh, J., \& Pattie, C. B. M. R. B. (2005). Children and young people's home use of ICT for educational purposes: The impact on attainment at key stages 1-4. University of Leeds. Retriewed from https://webarchive.nationalarchives.gov. uk/20130323014315/https://www.education.gov. uk/publications/eOrderingDownload/RR672.pdf

Witte, K. D., \& Rogge, N. (2014). Does ICT matter for effectiveness and efficiency in mathematics education? Computers \& Education, 75, 173-184. Doi:10.1016/j. compedu.2014.02.012

Wittwer, J., \& Senkbeil, M. (2008). Is students' computer use at home related to their mathematical performance at school? Computers \& Education, 50(4), 1558-1571. Doi:10.1016/j.compedu.2007.03.001 


\section{Appendix}

Table 1. Sample structure according to variables used in CHAID analysis

\begin{tabular}{|c|c|c|c|c|c|}
\hline Variable Name & Code & Label & Categories and Codes & Measurement & Types of Variables \\
\hline IC001Q02TA & $x_{2}$ & $\begin{array}{l}\text { Available for you to use at home: } \\
\text { Portable laptop, or notebook }\end{array}$ & $\begin{array}{c}\text { Never or hardly ever (1) } \\
\text { Once or twice a month (2) } \\
\text { Once or twice a week (3) } \\
\text { Almost every day (4) } \\
\text { Every day (5) }\end{array}$ & Nominal & Independent Variable \\
\hline IC001Q03TA & $X_{3}$ & $\begin{array}{l}\text { Available for you to use at home: } \\
\quad<\text { Tablet compu-ter }>\end{array}$ & $\begin{array}{c}\text { Never or hardly ever (1) } \\
\text { Once or twice a month (2) } \\
\text { Once or twice a week (3) } \\
\text { Almost every day (4) } \\
\text { Every day (5) }\end{array}$ & Nominal & Independent Variable \\
\hline IC001Q05TA & $X_{5}$ & $\begin{array}{l}\text { Available for you to use at home: } \\
\text { <Video games console }>\end{array}$ & $\begin{array}{c}\text { Never or hardly ever (1) } \\
\text { Once or twice a month (2) } \\
\text { Once or twice a week (3) } \\
\text { Almost every day (4) } \\
\text { Every day (5) }\end{array}$ & Nominal & Independent Variable \\
\hline IC001Q06TA & $X_{6}$ & $\begin{array}{c}\text { Available for you to use at home: } \\
<\text { Cell phone }>\text { (without Internet } \\
\text { access) }\end{array}$ & $\begin{array}{c}\text { Never or hardly ever (1) } \\
\text { Once or twice a month (2) } \\
\text { Once or twice a week (3) } \\
\text { Almost every day (4) } \\
\text { Every day (5) }\end{array}$ & Nominal & Independent Variable \\
\hline IC001Q08TA & $X_{8}$ & $\begin{array}{l}\text { Available for you to use at home: } \\
\text { Portable music player }\end{array}$ & $\begin{array}{c}\text { Never or hardly ever (1) } \\
\text { Once or twice a month (2) } \\
\text { Once or twice a week (3) } \\
\text { Almost every day (4) } \\
\text { Every day (5) }\end{array}$ & Nominal & Independent Variable \\
\hline IC001Q09TA & $X_{9}$ & $\begin{array}{c}\text { Available for you to use at home: } \\
\text { Printer }\end{array}$ & $\begin{array}{c}\text { Never or hardly ever (1) } \\
\text { Once or twice a month (2) } \\
\text { Once or twice a week (3) } \\
\text { Almost every day (4) } \\
\text { Every day (5) }\end{array}$ & Nominal & Independent Variable \\
\hline IC001Q10TA & $X_{10}$ & $\begin{array}{l}\text { Available for you to use at home: } \\
\text { USB (memory) stick }\end{array}$ & $\begin{array}{c}\text { Never or hardly ever (1) } \\
\text { Once or twice a month (2) } \\
\text { Once or twice a week (3) } \\
\text { Almost every day (4) } \\
\text { Every day (5) }\end{array}$ & Nominal & Independent Variable \\
\hline IC001Q11TA & $X_{11}$ & $\begin{array}{l}\text { Available for you to use at home: } \\
\text { <ebook reader> }\end{array}$ & $\begin{array}{c}\text { Never or hardly ever (1) } \\
\text { Once or twice a month (2) } \\
\text { Once or twice a week (3) } \\
\text { Almost every day (4) } \\
\text { Every day (5) }\end{array}$ & Nominal & Independent Variable \\
\hline IC009Q01TA & $X_{12}$ & $\begin{array}{l}\text { Digitial devices available at school: } \\
\text { Desktop com-puter }\end{array}$ & $\begin{array}{c}\text { Never or hardly ever (1) } \\
\text { Once or twice a month (2) } \\
\text { Once or twice a week (3) } \\
\text { Almost every day (4) } \\
\text { Every day (5) }\end{array}$ & Nominal & Independent Variable \\
\hline IC009Q02TA & $X_{13}$ & $\begin{array}{l}\text { Digitial devices available at school: } \\
\text { Portable laptop or notebook }\end{array}$ & $\begin{array}{c}\text { Never or hardly ever (1) } \\
\text { Once or twice a month (2) } \\
\text { Once or twice a week (3) } \\
\text { Almost every day (4) } \\
\text { Every day (5) }\end{array}$ & Nominal & Independent Variable \\
\hline IC009Q03TA & $X_{14}$ & $\begin{array}{l}\text { Digitial devices available at school: } \\
\quad<\text { Tablet compu-ter }>\end{array}$ & $\begin{array}{c}\text { Never or hardly ever (1) } \\
\text { Once or twice a month (2) } \\
\text { Once or twice a week (3) } \\
\text { Almost every day (4) } \\
\text { Every day (5) }\end{array}$ & Nominal & Independent Variable \\
\hline
\end{tabular}


The Investigation of the Relationship Between Mathematics and Science Literacy and ICT / Yılmaz Koğar

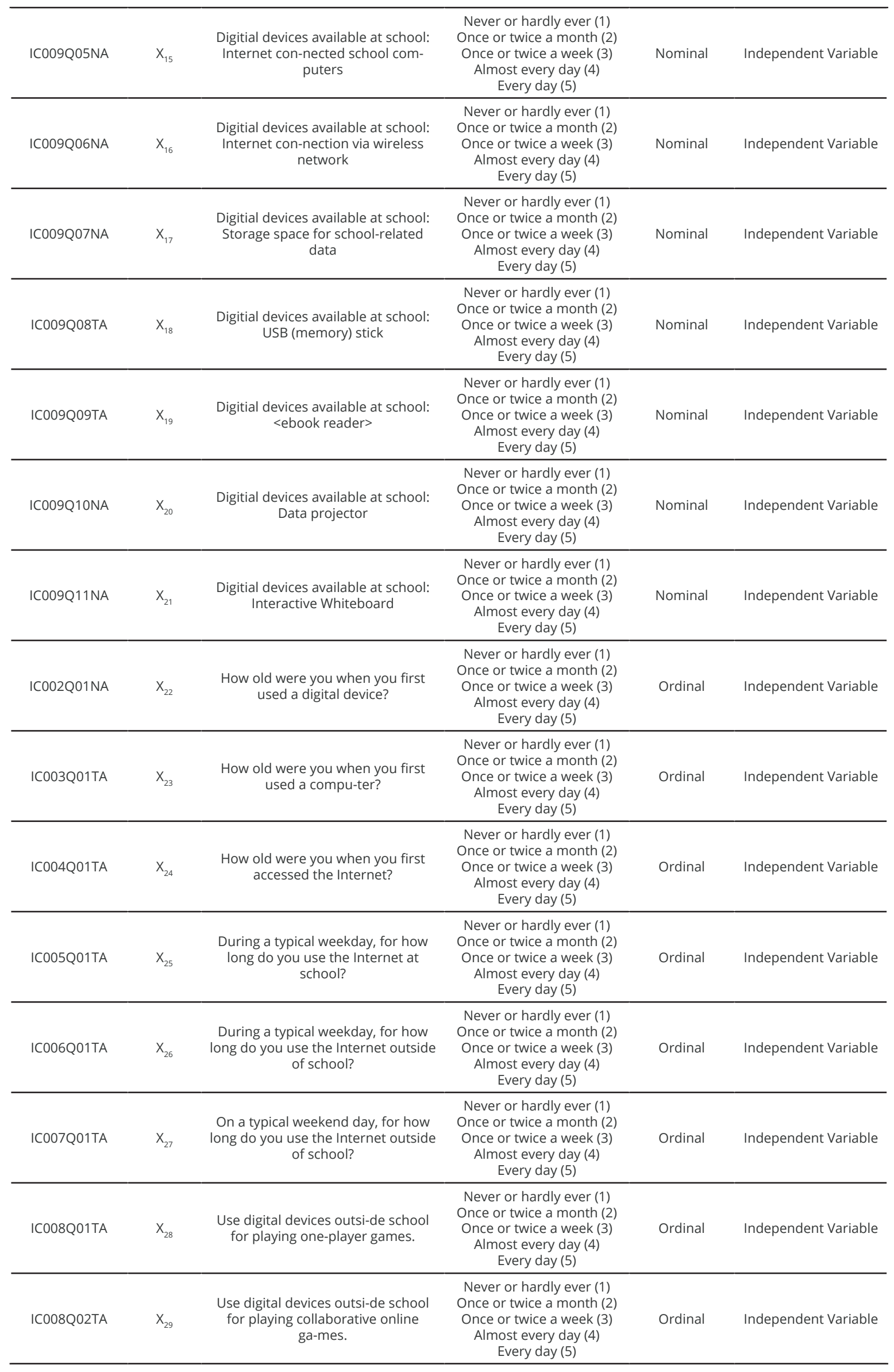




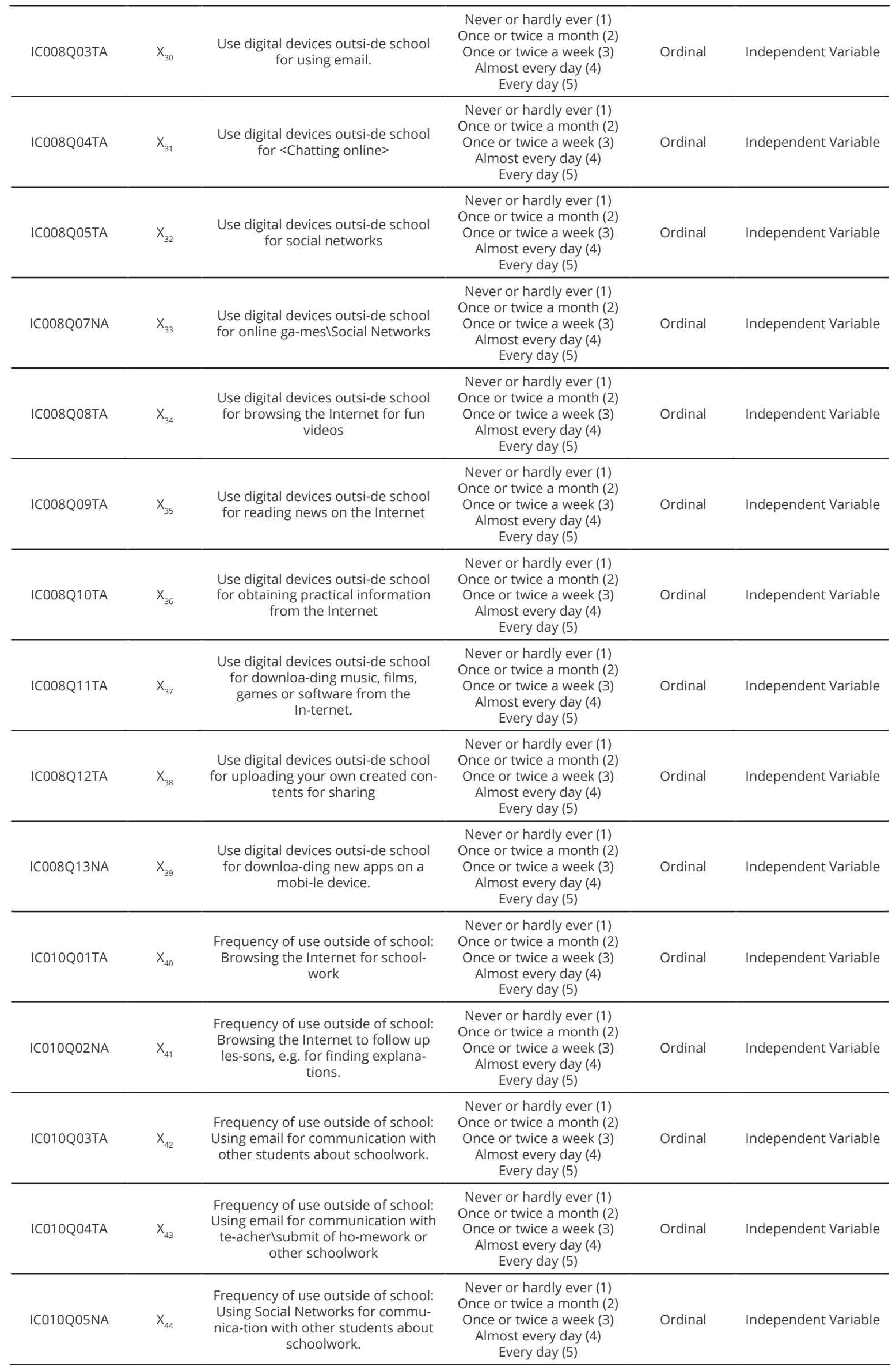


The Investigation of the Relationship Between Mathematics and Science Literacy and ICT / Yılmaz Koğar

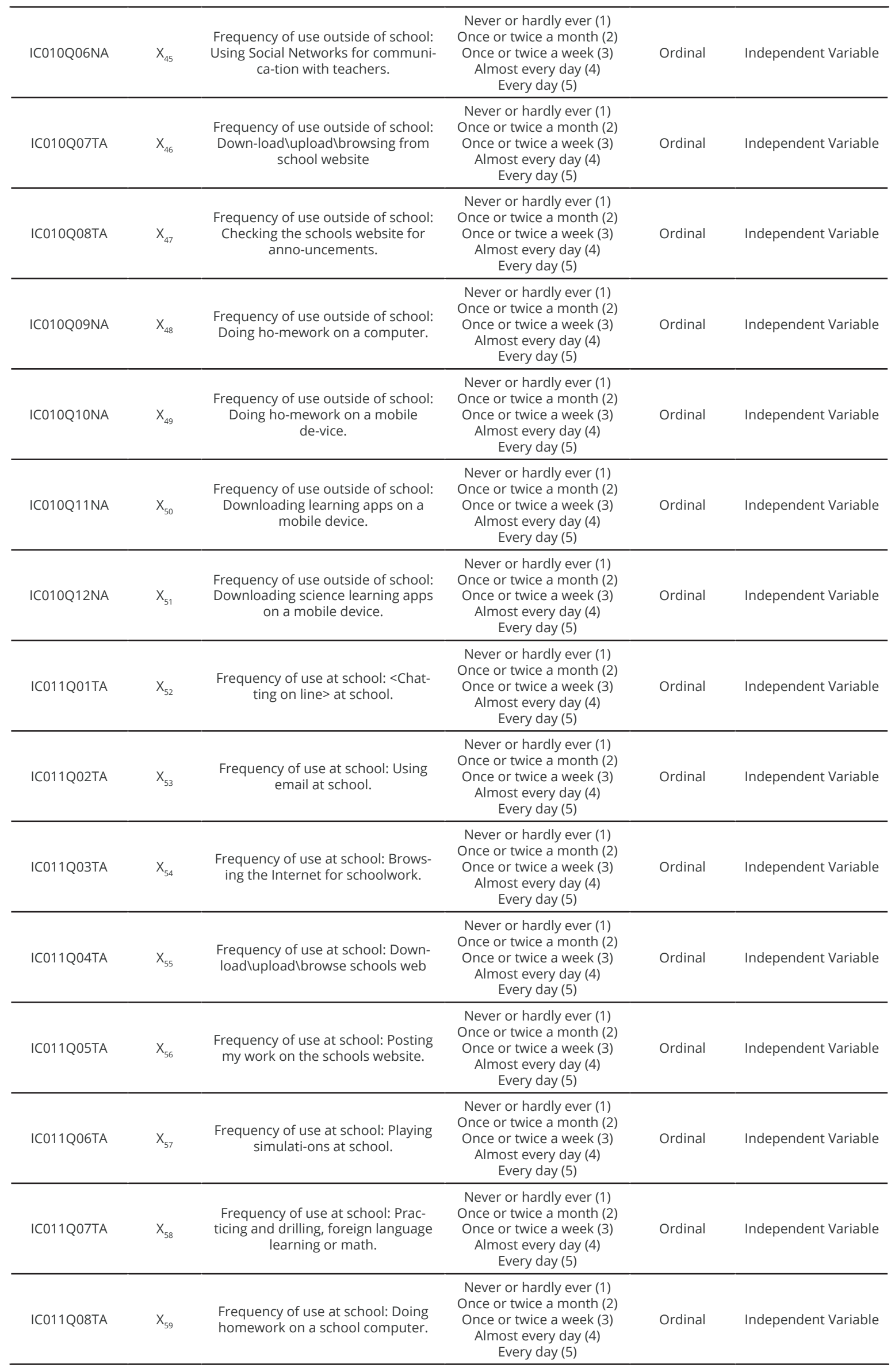




\begin{tabular}{|c|c|c|c|c|c|}
\hline IC011Q09TA & $X_{60}$ & $\begin{array}{c}\text { Frequency of use at school: Using } \\
\text { school computers for group work } \\
\text { and communication with other } \\
\text { students. }\end{array}$ & $\begin{array}{c}\text { Never or hardly ever (1) } \\
\text { Once or twice a month (2) } \\
\text { Once or twice a week (3) } \\
\text { Almost every day (4) } \\
\text { Every day (5) }\end{array}$ & Ordinal & Independent Variable \\
\hline IC013Q01NA & $X_{61}$ & $\begin{array}{l}\text { I forget about time when I'm using } \\
\text { digital devices. }\end{array}$ & $\begin{array}{l}\text { Strongly disagree (1) } \\
\text { Disagree (2) } \\
\text { Agree (3) } \\
\text { Strongly agree (4) }\end{array}$ & Ordinal & Independent Variable \\
\hline IC013Q04NA & $X_{62}$ & $\begin{array}{l}\text { The Internet is a great resource } \\
\text { for obtaining information I am } \\
\text { interes-ted in }\end{array}$ & $\begin{array}{l}\text { Strongly disagree (1) } \\
\text { Disagree (2) } \\
\text { Agree (3) } \\
\text { Strongly agree (4) }\end{array}$ & Ordinal & Independent Variable \\
\hline IC013Q05NA & $X_{63}$ & $\begin{array}{l}\text { It is very useful to have Social Net- } \\
\text { works on the Internet. }\end{array}$ & $\begin{array}{l}\text { Strongly disagree (1) } \\
\text { Disagree (2) } \\
\text { Agree (3) } \\
\text { Strongly agree (4) }\end{array}$ & Ordinal & Independent Variable \\
\hline IC013Q11NA & $X_{64}$ & $\begin{array}{l}\text { I am really excited disco-vering new } \\
\text { digital devices or applications. }\end{array}$ & $\begin{array}{l}\text { Strongly disagree (1) } \\
\text { Disagree (2) } \\
\text { Agree (3) } \\
\text { Strongly agree (4) }\end{array}$ & Ordinal & Independent Variable \\
\hline IC013Q12NA & $X_{65}$ & $\begin{array}{l}\text { I really feel bad if no Internet con- } \\
\text { nection is possible. }\end{array}$ & $\begin{array}{l}\text { Strongly disagree (1) } \\
\text { Disagree (2) } \\
\text { Agree (3) } \\
\text { Strongly agree (4) }\end{array}$ & Ordinal & Independent Variable \\
\hline IC013Q13NA & $X_{66}$ & I like using digital devi-ces. & $\begin{array}{l}\text { Strongly disagree (1) } \\
\text { Disagree (2) } \\
\text { Agree (3) } \\
\text { Strongly agree (4) }\end{array}$ & Ordinal & Independent Variable \\
\hline IC014Q03NA & $X_{67}$ & $\begin{array}{l}\text { I feel comfortable using digital de- } \\
\text { vices that I am less familiar with. }\end{array}$ & $\begin{array}{l}\text { Strongly disagree (1) } \\
\text { Disagree (2) } \\
\text { Agree (3) } \\
\text { Strongly agree (4) }\end{array}$ & Ordinal & Independent Variable \\
\hline IC014Q04NA & $X_{68}$ & $\begin{array}{l}\text { If my friends and relatives want to } \\
\text { buy new digital devices or applica- } \\
\text { tions, I can give them advice. }\end{array}$ & $\begin{array}{l}\text { Strongly disagree (1) } \\
\text { Disagree (2) } \\
\text { Agree (3) } \\
\text { Strongly agree (4) }\end{array}$ & Ordinal & Independent Variable \\
\hline IC014Q06NA & $X_{69}$ & $\begin{array}{l}\text { I feel comfortable using my digital } \\
\text { devices at ho-me. }\end{array}$ & $\begin{array}{l}\text { Strongly disagree (1) } \\
\text { Disagree (2) } \\
\text { Agree (3) } \\
\text { Strongly agree (4) }\end{array}$ & Ordinal & Independent Variable \\
\hline IC014Q08NA & $x_{70}$ & $\begin{array}{c}\text { When I come across prob-lems with } \\
\text { digital devices, I think I can solve } \\
\text { them. }\end{array}$ & $\begin{array}{l}\text { Strongly disagree (1) } \\
\text { Disagree (2) } \\
\text { Agree (3) } \\
\text { Strongly agree (4) }\end{array}$ & Ordinal & Independent Variable \\
\hline IC014Q09NA & $x_{71}$ & $\begin{array}{l}\text { If my friends and relatives have a } \\
\text { problem with digi-tal devices, I can } \\
\text { help them. }\end{array}$ & $\begin{array}{l}\text { Strongly disagree (1) } \\
\text { Disagree (2) } \\
\text { Agree (3) } \\
\text { Strongly agree (4) }\end{array}$ & Ordinal & Independent Variable \\
\hline IC015Q02NA & $x_{72}$ & $\begin{array}{l}\text { If I need new software, I install it by } \\
\text { myself. }\end{array}$ & $\begin{array}{l}\text { Strongly disagree (1) } \\
\text { Disagree (2) } \\
\text { Agree (3) } \\
\text { Strongly agree (4) }\end{array}$ & Ordinal & Independent Variable \\
\hline IC015Q03NA & $x_{73}$ & $\begin{array}{l}\text { I read information about digital } \\
\text { devices to be inde-pendent. }\end{array}$ & $\begin{array}{l}\text { Strongly disagree (1) } \\
\text { Disagree (2) } \\
\text { Agree (3) } \\
\text { Strongly agree (4) }\end{array}$ & Ordinal & Independent Variable \\
\hline IC015Q05NA & $x_{74}$ & $\begin{array}{l}\text { I use digital devices as I want to use } \\
\text { them. }\end{array}$ & $\begin{array}{l}\text { Strongly disagree (1) } \\
\text { Disagree (2) } \\
\text { Agree (3) } \\
\text { Strongly agree (4) }\end{array}$ & Ordinal & Independent Variable \\
\hline IC015Q07NA & $x_{75}$ & $\begin{array}{l}\text { If I have a problem with digital de- } \\
\text { vices I start to solve it on my own. }\end{array}$ & $\begin{array}{l}\text { Strongly disagree (1) } \\
\text { Disagree (2) } \\
\text { Agree (3) } \\
\text { Strongly agree (4) }\end{array}$ & Ordinal & Independent Variable \\
\hline IC015Q09NA & $x_{76}$ & $\begin{array}{l}\text { If I need a new applica-tion, I choose } \\
\text { it by my-self. }\end{array}$ & $\begin{array}{l}\text { Strongly disagree (1) } \\
\text { Disagree (2) } \\
\text { Agree (3) } \\
\text { Strongly agree (4) }\end{array}$ & Ordinal & Independent Variable \\
\hline IC016Q01NA & $x_{77}$ & $\begin{array}{l}\text { To learn something new about digi- } \\
\text { tal devices, I like to talk about them } \\
\text { with my friends. }\end{array}$ & $\begin{array}{l}\text { Strongly disagree (1) } \\
\text { Disagree (2) } \\
\text { Agree (3) } \\
\text { Strongly agree (4) }\end{array}$ & Ordinal & Independent Variable \\
\hline
\end{tabular}


The Investigation of the Relationship Between Mathematics and Science Literacy and ICT / Yılmaz Koğar

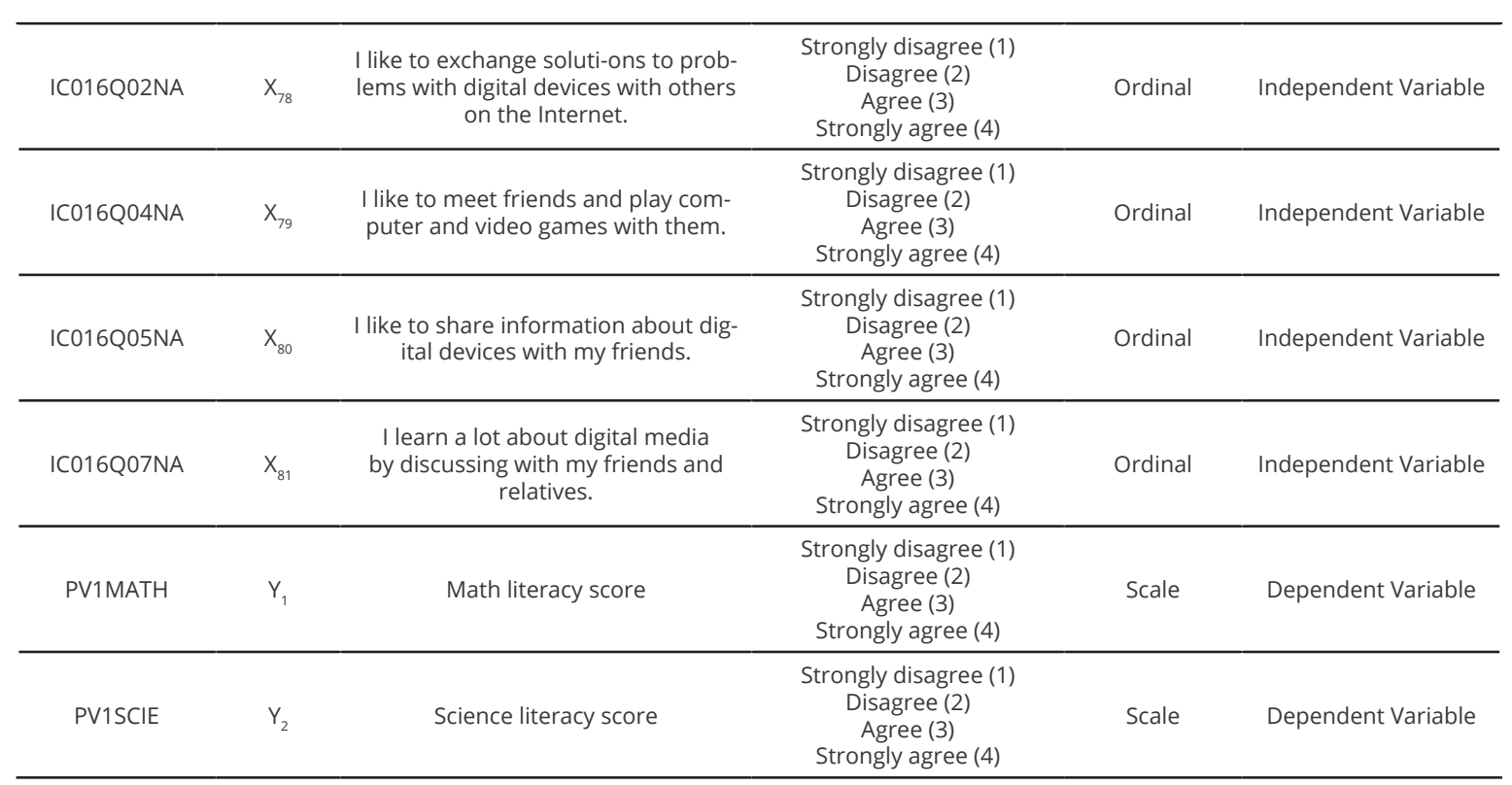

